\title{
Analisis Ke-Ekonomian Pemidanaan Tindak Pidana Pencucian Uang Dalam Undang-Undang Nomor 8 Tahun 2010 Tentang Pencegahan Dan Pemberantasan Tindak Pidana Pencucian Uang
}

\author{
Erma Denniagi \\ Magister Hukum Fakultas Hukum Universitas Islam Indonesia Yogyakarta Indonesia \\ Jln. Cik Di Tiro No. 1 Yogyakarta Indonesia \\ ermadenniagi93.ed@gmail.com
}

\begin{abstract}
The problem of money laundering is not only related law enforcement issues, but is also directly related and has an impact on the national financial and economic problems, including the national investment issues. The formulation of the problem raised is whether the punishment in Law Number 8 of 2010 on the Prevention and Eradication of the Crime of Money Laundering has reflected the principle of cost and benefit principal? This is a normative legal research through literature study (legal approach) and the study of theories, views, or doctrines in legal science in order to provide concepts, which will then be presented descriptively. The results of this study indicate that the criminal offense of money laundering in Law no. 8 of 2010 has not fully reflected the principle of economic analysis of law, namely the cost and benefit principle, so it tends to create inefficient penalties. Therefore, the recommendation in this study is to optimize the achievement of proportional punishment for money laundering, so that it is more efficient in preventing and eradicating the crime of money laundering.
\end{abstract}

Key Words: Economic analysis of criminal law; money laundering; proportional punishment

\begin{abstract}
Abstrak
Masalah tindak pidana pencucian uang tidak hanya berkaitan dengan masalah hukum dan penegakan hukum semata, melainkan juga berkaitan langsung dan berdampak terhadap masalah keuangan dan perekonomian nasional, termasuk masalah investasi nasional. Adapun rumusan masalah yang diangkat apakah pemidanaan dalam Undang-Undang Nomor 8 Tahun 2010 tentang Pencegahan dan Pemberantasan Tindak Pidana Pencucian Uang sudah mencerminkan prinsip cost and benefit principal?. Penelitian ini adalah penelitian hukum normatif melalui studi kepustakaan (pendekatan perundang-undangan) dan studi atas teori, pandangan, atau doktrin di dalam ilmu hukum guna memberikan konsep, yang kemudian akan disajikan secara deskriptif. Hasil penelitian ini menyimpulkan bahwa pemidanaan tindak pidana pencucian uang dalam UU No. 8 Tahun 2010 belum sepenuhnya mencerminkan prinsip economic analysis of law, yaitu cost and benefit principle, sehingga cenderung menciptakan pemidanaan yang tidak efisien (inefisiensi). Karena itu, rekomendasi dalam penelitian ini nantinya diharapkan dapat mengoptimalkan tercapainya pemidanaan yang proporsional untuk tindak pidana pencucian uang, sehingga lebih efisien dalam rangka mencegah dan memberantasan tindak pidana pencucian uang.
\end{abstract}

Kata-kata Kunci: tindak pidana pencucian uang; economic analysis of criminal law; pemidanaan yang proporsional 


\section{Pendahuluan}

Menganalisis hukum dapat dilakukan dengan berbagai pendekatan (approaches). Salah satunya adalah mengkaji hukum atas dasar analisa ekonomi (economic analysis of law). Ide economic analysis of law (analisis ekonomi terhadap hukum) dianggap muncul pertama kali oleh Jeremy Bentham sebagai penganut paham utilitarianisme. Menurut Bentham, efektifitas keberlakuan hukum dapat diukur dengan indikator nilai yang terkandung dalam suatu ketentuan hukum (dapat ditegakkan), berdaya guna (berfungsi sesuai dengan tujuan pembentukkannya), dan efisiensi (pemberlakuannya untuk kesejahteraan orang banyak). Efisiensi dalam hal ini adalah suatu hal yang terarah pada social welfare atau good law, dipandang dalam pertimbangan keuntungan/kesenangan dan kerugian/penderitaan (cost and benefit).

Apabila melihat pada kenyataan yang terjadi hingga saat ini, perlu dipahami bahwa peristiwa hukum bukan lagi hanya sekedar perilaku taat atau melanggar hukum, tetapi juga harus dipahami sebagai perilaku manusia yang secara rasional dikuasai oleh dua kekuatan, yakni kesenangan dan penderitaan. Artinya, setiap perilaku manusia, termasuk perilaku taat atau melanggar hukum akan selalu mempertimbangkan untuk mencapai kesenangan/keuntungan sebesar-besarnya dan beban penderitaan/kerugian sekecil-kecilnya. Dengan menggunakan analisa ekonomi, maka hukum pidana khususnya yang memuat beberapa kritikan atas hukum nantinya tidak lagi hanya dipandang dalam penilaian moral (benar/right dan salah/wrong), tetapi juga perlu dipertimbangkan dari sisi keuntungan dan kerugian (cost and benefit) bagi negara dan masyarakat serta kepentingan pelaku. Pendekatan ini sangat diperlukan pada kasus-kasus atau dalam hal menanggulangi tindak pidana dalam bidang ekonomi, salah satunya adalah tindak pidana pencucian uang.

Masalah tindak pidana pencucian uang jelas bukan masalah hukum dan penegakan hukum semata, melainkan juga berkaitan langsung dan berdampak terhadap masalah keuangan dan perekonomian nasional, termasuk masalah investasi nasional. Tindak pidana pencucian uang sepertinya tidak menimbulkan korban atau menimbulkan kerugian bagi korbannya sebagaimana tindak pidana konvensional lainnya, seperti pembunuhan atau pencurian. Namun dalam realitanya, terjadi akumulasi dana oleh aktivitas pencucian uang dalam jumlah yang sangat besar dan mengganggu stabilitas sistem keuangan. Dampak tindakan ini secara makro dapat mempersulit pengendalian moneter, mengurangi 
pendapatan negara, dan meningkatnya country risk ${ }^{1}$. Sementara, dampak secara mikro akan menimbulkan high cost economy ${ }^{2}$ serta menimbulkan persaingan usaha yang tidak sehat. ${ }^{3}$

Fokus pembentuk undang-undang dalam upaya penanggulangan tindak pidana pencucian uang hingga saat ini melalui pencegahan dan penindakan semata melalui pendekatan hukum pidana ${ }^{4}$, yaitu pemidanaan atau pidana yang dijatuhkan dilandasi oleh teori pemidanaan retributif atau pembalasan semata ${ }^{5}$. Pemidanaan tindak pidana pencucian uang tersebut diatur dalam UndangUndang Nomor 8 Tahun 2010 tentang Pencegahan dan Pemberantasan Tindak Pidana Pencucian Uang (UU TPPU). Tindak pidana tersebut yang masih memberlakukan pidana penjara jangka panjang berakibat dapat mengganggu stabilitas perekonomian secara makro ${ }^{6}$ dan cenderung terjadi pengenaan pidana yang ganda yakni menyertai pidana penjara dengan pidana denda. Namun, tetap saja pidana penjara akan lebih diutamakan, sebab berdasarkan Pasal 8 UU TPPU pidana denda dapat saja diganti dengan pidana kurungan apabila harta terpidana tidak cukup untuk membayar pidana denda.

${ }^{1}$ Disebutkan dalam Peraturan Kepala Pusat Pelaporan dan Analisis Transaksi Keuangan Nomor: PER02/1.02/PPATK/02/15 tentang Kategori Pengguna Jasa yang Berpotensi Melakukan Tindak Pidana Pencucian Uang, bahwa Negara yang Beresiko (country risk) adalah negara yang potensial digunakan sebagai tempat: (a) terjadinya atau sarana tindak pidana pencucian uang; (b) dilakukannya tindak pidana asal (predicate offense); dan/atau (c) dilakukannya aktivitas pendanaan kegiatan terorisme.

${ }^{2}$ High cost economy atau ekonomi berbiaya tinggi merupakan aktivitas perekonomian yang menciptakan biaya tinggi karena inefisiensi atau praktik korupsi. High cost economy ini dihasilkan oleh praktik ekonomi yang ilegal yang memainkan peran penting dalam membantu mempercepat tekanan inflasi, selain sebagai penghambat faktor fundamental seperti nilai tukar rupiah dan persediaan barang dan uang, pun memiliki kelebihan besar biaya dibandingkan dengan lainnya yang sebenarnya kecenderungan ini merupakan hambatan tinggi untuk masuknya industri di mana masalah biaya menonjol dan dalam penciptaan skala ekonomi yang besar dalam kaitannya dengan ukuran pasar modern air bersih, energi, telekomunikasi dan listrik adalah sangat mahal untuk membangun jaringan transmisi (jaringan pipa air, gas, listrik, dan saluran telepon). Dalam id.wikipedia.org.

3 Haswandi et.al., Sistem Pemidanaan Terbadap Pelaku Tindak Pidana Pencucian Uang, Cetakan Pertama, Puslitbang Hukum dan Peradilan Mahkamah Agung RI, Jakarta, 2017, hlm. 21.

${ }^{4}$ Dalam penjelasan Romli Atmasasmita mengenai "pengembalian asset" dan "perampasan asset" sebagai bagian dari pemidanaan, bahwa harapan perbaikan dalam pencegahan kerugian negara melalui Undang-Undang Nomor 20 Tahun 2001 tentang Perubahan Atas Undang-Undang Nomor 31 Tahun 1999 tentang Pemberantasan Tindak Pidana Korupsi dan Undang-Undang Nomor 8 Tahun 2010 tentang Pencegahan dan Pemberantasan Tindak Pidana Pencucian Uang, masih jauh dari harapan pemerintah, karena pertama, pemerintah dan DPR RI belum memahami keterkaitan dan relevansi hubungan kedua undang-undang tersebut; kedua, fokus pembentuk undang-undang adalah pencegahan dan penindakan semata-mata melalui pendekatan hukum pidana; ketiga, dalam penyusunan kedua undang-undang tersebut masih mengutamakan pendekatan normative (hukum pidana semata-mata) dengan pengaruh kuat dari aliran kantianisme (Kant, Bentham, Austin); keempat, penyusun kedua undang-undang tersebut tidak mempertimbangkan perkembangan kondisi sosial dan ekonomi Indonesia di tengah-tengah peta politik ekonomi global. Dalam Roberts K, Pengembalian Aset Hasil Kejahatan dalam Perspektif Rezim Anti Pencucian Uang,Cetakan Pertama, Rajawali Pers, Depok, 2017, hlm. 74.

${ }_{5}$ Pathorang Halim, Penegakan Hukum terhadap Kejahatan Pencucian Uang di Era Globalisasi, Cetakan Pertama, Total Media, Yogyakarta, 2013, hlm. 121.

${ }_{6}$ Mayoritas pemidanaan yang menggunakan pidana penjara yang tidak efisien karena menghabiskan terlalu banyak anggaran yang mana tidak sesuai dengan kerugian yang dialami korban bahkan beberapa justru tidak mampu mengembalikan kerugian yang diderita korban, tentu akan mempengaruhi perekonomian secara makro yakni mengenai pendapatan nasional dan pertumbuhan ekonomi negara. 
Tujuan pemidanaan sebagai pembalasan dengan melalui sistem penjara seperti itu tidak memberikan solusi yang memuaskan, sebab instrumen yang diharapkan mampu menimbulkan efek jera dan menghentikan kejahatan yang terjadi dalam masyarakat justru lebih banyak menimbulkan keresahan terhadap kesejahteraan masyarakat. Selain itu, harapan pengembalian harta kekayaan hasil tindak pidana dan pencegahan kerugian negara sebagaimana telah termuat dalam UU TPPU itu pun dirasa masih jauh dari harapan pemerintah hingga saat ini, sebab tidak adanya kontribusi yang signifikan terhadap pemulihan perekonomian negara (benefit) dan justru dari sisi waktu dan biaya menjadi tidak efisien dan efektif.

\section{Rumusan Masalah}

Apakah pemidanaan dalam Undang-Undang Nomor 8 Tahun 2010 tentang Pencegahan dan Pemberantasan Tindak Pidana Pencucian Uang sudah mencerminkan prinsip cost and benefit principal?

\section{Tujuan Penelitian}

Penelitian ini bertujuan untuk menganalisis apakah pemidanaan dalam Undang-Undang Nomor 8 Tahun 2010 tentang Pencegahan dan Pemberantasan Tindak Pidana Pencucian Uang sudah mencerminkan prinsip dalam economic analysis of law, yaitu cost and benefit principal.

\section{Metode penelitian}

Penelitian ini adalah penelitian hukum normatif yang menggunakan pendekatan perundang-undangan (statute approach), yaitu dalam hal ini adalah mengkaji pemidanaan tindak pidana pencucian uang dalam UU No. 8 Tahun 2010 tentang Pencegahan dan Pemberantasan Tindak Pidana Pencucian Uang dan pendekatan konseptual (conceptual approach) yaitu yang akan beranjak pada teori, pandangan, atau doktrin di dalam ilmu hukum guna memberikan pengertian, konsep, maupun asas hukum yang relevan dengan permasalahan dalam penelitian nantinya. Pengumpulan bahan hukum dalam penelitian ini akan dilakukan dengan cara studi pustaka, yaitu suatu cara pengumpulan bahan hukum dengan menelaah bahan pustaka yakni literatur, jurnal, artikel, dan sebagainya yang berhubungan dengan masalah dalam penelitian ini, serta mempelajari undang-undang dan putusan yang berhubungan dengan masalah dalam penelitian itu. Analisis masalah dalam penelitian ini akan menggunakan analisis ekonomi terhadap hukum (economic analysis of law) dalam memecahkan isu hukum mengenai pemidanaan dalam tindak pidana pencucian uang saat ini. 
Penggunaan analisis ekonomi tersebut hanya sebatas untuk mengkritisi isu hukum dalam penelitian ini yang dihadapkan dengan prinsip-prinsip economic analysis of law, sehingga dapat disajikan secara deskriptif.

\section{Hasil Penelitian dan Pembahasan}

\section{Proporsionalitas dalam Pemidanaan TPPU}

Mengenai ide proporsionalitas atau dikenal juga dengan prinsip kesetimpalan ini akan lebih banyak terkait dengan tujuan pemidanaan, yaitu retributif maupun preventif. Dalam masalah proporsionalitas pidana, aspek retributif dan preventif tidak mungkin dipisahkan, meskipun pada awalnya teori retributif yang memperkenalkan masalah proporsionalitas dalam pemidanaan. ${ }^{7}$ Hal ini dengan alasan bahwa penggunaan aspek retributif saja akan berpotensi untuk menghilangkan tujuan pemidanaan terhadap penanggulangan kejahatan itu sendiri, sebab tindakan yudisial tersebut hanya akan menjadi pengenaan penderitaan tanpa manfaat.

Aspek retributif dan aspek preventif harusnya bukan dipahami sebagai pilihan dalam justifikasi pemidanaan, tetapi lebih sebagai suatu kecenderungan yang memungkinkan dalam waktu dan keadaan tertentu ke arah retributif atau ke arah preventif, yang mana didasarkan pada adanya kebijakan negara melalui suatu peraturan perundang-undangan tertentu. Alasan mengapa aspek retributif bukan merupakan justifikasi pemidanaan tetapi adalah suatu dasar etik adanya pemidanaan, adalah bahwa negara tidak akan mempunyai hak untuk menjatuhkan pidana terhadap seseorang kecuali atas tindak pidana yang dapat dipersalahkan terhadap orang tersebut.

Di sisi lain, aspek preventif juga seharusnya bukanlah justifikasi pidana, sebab tidak mungkin suatu justifikasi didasarkan pada hasil yang belum diketahui kepastiannya. Karena itu, aspek preventif ini lebih tepat disebut sebagai suatu tujuan pemidanaan yang akan memberikan arah atau hasil yang ingin dicapai oleh hukum pidana atau aturan perundang-undangan pidana tersebut. Nantinya, tujuan preventif tidak harus diwujudkan dalam bentuk pidana yang demikian ringan, melainkan dalam keadaan tertentu dapat diwujudkan dalam bentuk pidana yang berat tergantung pada dampak pemidanaan yang ingin dicapai. ${ }^{8}$

${ }^{7}$ Hal ini didasarkan pada maksud teori retributive dalam pemidanaan adalah bahwa pidana dijatuhkan sebagai bentuk balasan yang setimpal atas perbuatan pidana yang dilakukan pelaku Disebutkan juga dalam penjelasan Mirko Bagaric, Punishment and Sentencing: A Rational Approach, First Edition, Cavendish Publishing Limited, London, 2001.

${ }_{8}$ Didasarkan pada penjelasan dalam Muhammad Ainul Syamsu, Penjatuban Pidana dan Dua Prinsip Dasar Hukum Pidana, Cetakan Pertama, Kencana, Jakarta, 2016, hlm. 158. 
Berdasarkan pada pengertian tersebut, dapat dikatakan bahwa dalam pandangan retributif, proporsionalitas (kesetimpalan) adalah dasar pemidanaan atas pelaku yang dianggap pantas dijatuhkan pidana apabila syarat pemidanaannya terpenuhi, yakni mengenai tindak pidana dan pertanggungjawaban pidana (kesalahan). Kemudian, dalam pandangan preventif, proporsionalitas dipandang sebagai limiting principle atau prinsip pembatas yang melarang pemidanaan yang tidak sepadan dengan tindak pidana dan kesalahan pelaku. Oleh karena itu, dalam hal tercapainya proporsionalitas pemidanaan, fungsi preventif perlu diletakkan sebagai fungsi pendukung dari aspek retributif yang menekankan pidana pada hard treatment terhadap pelaku. Dalam konteks proposionalitas, tujuan pemidanaan adalah memberikan manfaat baik terhadap pelaku, korban, maupun masyarakat yang mana didukung dengan prinsip retributif yang mengharuskan bahwa pidana hanya dijatuhkan terhadap pelaku tindak pidana. ${ }^{9}$

Dalam teori-teori tujuan pemidanaan, baik retributif atau preventif bukan sebagai defining principle yang mendefinisikan jumlah pasti pidana yang dijatuhkan berdasarkan asas proporsionalitas, tetapi lebih kepada menentukan hubungan antara tindak pidana dan pidana tersebut sebagai kerangka acuan dalam penjatuhan pidana (pemidanaan). ${ }^{10}$ Didasarkan pada hal tersebut, maka pemidanaan yang proporsional mengharuskan adanya pidana yang sepadan dengan tindak pidana yang dilakukan. Dalam pandangan economic analysis of law sendiri, hal itu bersesuain dengan prinsip "let the punishment fit the crime" yang dicetuskan oleh Cesare Beccaria. Menurut Beccaria, perlu adanya kesebandingan antara pidana dan tindak pidana. Bukan karena kepentingan umum bahwa kejahatan tidak boleh dilakukan, tetapi bahwa kejahatan jenis apapun harus berkurang, sebanding dengan beratnya kerugian yang diderita oleh masyarakat karena kejahatan tersebut. ${ }^{11}$ Karena itu, beratnya pidana akan disesuaikan dengan tingkat keseriusan tindak pidana. Andrew von Hirsch menyebutkan bahwa beratnya hukuman harus proporsional dengan beratnya pelanggaran ${ }^{12}$ atau kejahatan yang dilakukan. Dengan demikian, dapat dikatakan bahwa dalam konteks proporsionalitas pemidanaan layak dilakukan bukan dilihat dari jumlah dan kuantitas pidana, melainkan tujuan pemidanaan yang mengutamakan

${ }^{9}$ Ibid.

10 Hal ini sebagaimana pendapat Andrew von Hirsch dalam bukunya Censure and Sanction yang menyebutkan mengenai just desert model (model ganjaran setimpal) yang mana didasarkan pada dua teori tentang tujuan pemidanaan, yakni retribution dan prevention, Ibid., hlm. 154.

11 Lidya Suryani Widayati, "Pidana Mati dalam RUU KUHP: Perlukah Diatur sebagai Pidana yang Bersifat Khusus?”, Jurnal Negara Hukum, Edisi No. 2 Vol. 7, 2016, hlm. 173.

12 Joel Goh, "Proportionality-An Unattainable Ideal in the Criminal Justice System", Manchester Student Law Review, Edisi No. 41 Vol. 2, 2013, hlm. 43-44. 
perhatian terhadap kualitas pidana dalam pengertian dampak pemidanaan (baik terhadap pelaku, korban, maupun masyarakat luas).

Konsep proporsionalitas pemidanaan ini juga tampak pada konsep pemidanaan terhadap tindak pidana pencucian uang sebagaimana diatur dalam UU No. 8 Tahun 2010. Dalam rangka mencegah dan memberantas tindak pidana pencucian uang ${ }^{13}$, bahwa tujuan pemidanaan terhadap tindak pidana pencucian uang adalah tidak hanya terbatas pada menjerakan pelaku dengan cara memaksimalkan ancaman pidana saja (represif), tetapi juga untuk upaya pemulihan aset (asset recovery) atas proceed of crime (preventif) melalui penelusuran dan pengembalian harta kekayaan hasil tindak pidana. Artinya, pemidanaan terhadap tindak pidana pencucian uang dilakukan tidak hanya sebagai cara untuk menangkap pelaku kejahatan asal, tetapi sekaligus dapat merampas kembali hasil kejahatan untuk dikembalikan kepada yang berhak. ${ }^{14}$

\section{Pemidanaan TPPU dalam UU No. 8 Tahun 2010 Belum Sepenuhnya Mencerminkan Cost and Benefit Principal}

Aktifitas atau perbuatan yang lebih berbahaya sudah seharusnya akan memperoleh sanksi yang lebih berat dibandingkan yang lain. ${ }^{15}$ Pengaruh tindak pidana pencucian uang yang sangat berbahaya terhadap keuangan dan perekonomian suatu negara, maka tindak pidana ini digolongkan sebagai salah satu kejahatan luar biasa (extraordinary crime) dan layak diberikan sanksi pidana yang berat. UU No. 8 Tahun 2010 menetapkan maksimalisasi pemidanaan terhadap tindak pidana pencucian uang, yaitu selain dengan pidana yang berat (kumulasi pidana penjara dan pidana denda) juga adanya kewajiban para penegak hukum dalam rangka recovery aset hasil tindak pidana, seperti perampasan aset milik pelaku tindak pidana tersebut. Hal ini diharapkan akan membangkitkan kepatuhan, menjerakan pelaku, serta mencegah orang lain atau masyarakat untuk tidak melakukan tindak pidana tersebut.

Sutherland menyatakan bahwa "the amount of pain thus attached must be made known to all, that prospective criminals can make rational calculation."16 Berdasarkan pendapat Sutherland tersebut, bahwa pidana yang berat itu dipersamakan dengan rasa sakit yang akan diderita pelaku tindak pidana, dan rasa sakit ini menurut Sutherland harus diberitahukan pada orang lain atau masyarakat luas agar calon

${ }_{13}$ Didasarkan pada Penjelasan UU No. 8 Tahun 2010 tentang Pencegahan dan Pemberantsaan Tindak Pidana Pencucian Uang.

14 Yenti Garnasih, Penegakan Hukum Anti Pencucian Uang dan Permasalahannya di Indonesia, Cetakan Keempat, Rajawali Pers, Depok, 2017, hlm. 1.

15 Johnny Ibrahim, Pendekatan Ekonomi terhadap Hukum: Teori dan Implikasi dalam Penegakan Hukum, Cetakan Pertama, Putra Media Nusantara dan ITS Press, Surabaya, 2009, hlm. 66.

16 Iqrak Sulhin, Diskontinuitas Penologi Punitif: Sebuah Analisis Genealogis terhadap Pemenjaraan, Cetakan Pertama, Kencana, Jakarta, 2016, hlm. 36-37. 
pelaku tindak pidana dapat memperhitungkan secara rasional untuk melakukan tindak pidana. Ricard A Posner menyebut manusia sebagai homo economicus yang akan selalu dihadapkan pada keadaan nyata yang mengharuskan untuk memilih secara rasional terhadap pilihan-pilihan ekonomis. Lebih lanjut, Jeremy Bentham menyebutkan bahwa manusia merupakan makhluk yang rasional yang akan memilih secara sadar sebuah kesenangan (menghasilkan benefit untuk dirinya) dan menghindari kesusahan (menghindarkan pada cost yang dapat merugikan dirinya). Oleh karena itu, dalam kaitannya dengan pemidanaan, bahwa suatu pidana harus ditetapkan pada tiap kejahatan sedemikian rupa, sehingga kesusahan akan lebih berat dari pada kesenangan yang ditimbulkan oleh kejahatan. ${ }^{17}$ Dapat dikatakan bahwa pemidanaan tidak hanya memerlukan legitimasi, tetapi juga memerlukan rasionalitas.

Dalam konsep rasionalitas, kejahatan atau tindak pidana merupakan perilaku yang timbul karena individu adalah pencari kesenangan (benefit) dan menghindari penderitaan (cost). Hal ini sebagaimana Jeremy Bentham dan Cesare Beccaria sebagai pelopor paham utilitarianisme tentang pemidanaan menyebutnya dengan konsep pemidanaan yang didasarkan pada pemahaman hedonistik terhadap kejahatan. Setiap individu memiliki kehendak yang bebas dalam kalkulasi hedonistik, karenanya kejahatan dianggap sebagai hasil dari kalkulasi untung rugi. ${ }^{18}$ Bersesuaian dengan hal tersebut, Michael Trebilcock juga menyebutkan bahwa sebagian besar orang adalah pelaku rasional (rational actor) yang secara rasional menghitung biaya dan benefit dari berbagai alternatif pilihan tindakannya, dan karenanya akan mengambil pilihan yang memaksimalkan net benefit pribadi yang diharapkan. ${ }^{19}$

Pelaku kejahatan atau pelanggar hukum sebagai rational actor akan berusaha memaksimalkan utilitas mereka dalam konteks kriminal. Para pelaku sebagai rational actor akan membandingkan cost yang diharapkan dari kegiatan kriminal tersebut dengan benefit yang diharapkannya. Benefit yang diharapkan adalah termasuk keuntungan yang berasal dari kegiatan kriminal. Hal ini dapat berwujud berupa barang, uang, atau harta kekayaan lainnya ataupun tidak berwujud berupa rasa sakit dan penderitaan bagi korban. Cost tindakan kriminal dalam konteks ini termasuk sumber daya yang dikeluarkan untuk melakukan tindakan kriminal dan terpenting adalah cost yang diharapkan dari hukuman pidana. Dengan demikian, ketika seseorang melakukan kejahatan, maka pada

${ }^{17}$ Muladi dan Barda Nawawi Arief, Teori-Teori dan Kebijakan Pidana, Cetakan Keempat, Alumni, Bandung, 2010, hlm. 30.

18 Penjelasan Iqrak Sulhin, Op. Cit., hlm. 36.

19 Dalam penjelasan Romli Atmasasmita dan Kodrat Prabowo, Analisis Ekonomi Mikro tentang Hukum Pidana Indonesia, Cetakan Kedua, Kencana, Jakarta, 2016, hlm. 37. 
dasarnya terdapat kesenangan yang lebih besar dari dilakukan kejahatan tersebut dibandingkan dengan tidak melakukannya. ${ }^{20}$

Manusia dapat saja mengambil sebuah keputusan yang buruk, namun bukan berarti hal itu menjadikan manusia irasional. Setiap manusia memiliki rasionalitas dalam batas minimal ketika mengambil suatu keputusan yang didasarkan dan dipertimbangkan dengan seluruh informasi yang dimilikinya. Artinya, setiap pelaku kejahatan, termasuk dalam konteks ini pelaku tindak pidana pencucian uang, memiliki penilaian yang subjektif terhadap keputusan untuk melakukan tindak pidana, yang mana dengan mempertimbangkan jumlah keuntungan (benefit) dan kerugian (cost) yang tentu saja akan berbeda dari masing-masing pelaku. ${ }^{21}$

Tindak pidana pencucian uang itu akan tetap dilakukan meskipun telah diatur pemidanaan yang sedemikian berat dan merupakan hal yang wajar apabila terjadi peningkatan jumlah dilakukannya tindak pidana pencucian uang hingga saat ini. Semakin tinggi dan meningkatnya angka rata-rata kejahatan ini, menurut Johannes Andenaes merupakan bukti kegagalan atau ketidakmampuan sistem yang ada sekarang. ${ }^{22}$ Berdasarkan data statistik yang disusun oleh PPATK ${ }^{23}$ sendiri menunjukan bahwa jumlah keseluruhan laporan yang telah diterima PPATK sejak Januari 2003 sampai dengan Desember 2020 telah mencapai 85.034.031 laporan. Terjadi peningkatan sebanyak 12,8 persen dibandingkan dengan jumlah kumulatif laporan perakhir Desember 2019. Namun hingga Desember 2020, hanya terdapat 549 kasus yang telah diputus oleh pengadilan sejak UU TPPU diberlakukan dan apabila diakumulasikan sejak Januari 2005, maka jumlah yang tercatat adalah 456 kasus dengan rincian hukuman berupa pidana penjara maksimal seumur hidup dan pidana denda maksimal Rp. 32.000.000.000,00.

Berdasarkan data tersebut menunjukan bahwa perkembangan jumlah tindak pidana pencucian uang terus meningkat meskipun sejak diberlakukannya UU No. 8 Tahun 2010 dengan pemidanaan yang demikian berat. Hal ini tidak sebanding dengan jumlah keberhasilan penyelesaian tindak pidana pencucian uang melalui pemidanaan yang diputus oleh pengadilan dan dapat dikatakan bahwa hal demikian itu sebagai bukti ketidakmampuan dan inefisiensi sistem pemidanaan tindak pidana pencucian uang yang ada.

${ }^{20}$ Penjelasan Iqrak Sulhin, Loc. Cit.

${ }^{21}$ Didasarka pada penjelasan dalam Andreas Nathaniel Marbun dan Revi Laracaka, "Analisa Ekonomi terhadap Hukum dalam Pemidanaan Partai Politik melalui Pertanggungjawaban Korporasi dalam Perkara Tipikor", Jurnal Antikorupsi, (2019), hlm. 134-135.

${ }^{22}$ Muladi dan Barda Nawawi Arief, Op. Cit., hlm. 196.

${ }^{23}$ Buletin Statistik "Anti Pencucian Uang dan Pencegahan Pendanaan Terorisme”, Edisi Desember 2020, Volume 130/THN X/2020. 
Dapat ditarik kesimpuan bahwa ringannya rumusan pemidanaan dalam suatu peraturan perundang-undangan pidana bukan merupakan jaminan untuk dapat menghentikan seseorang untuk melakukan tindak pidana. Namun dalam konteks pencucian uang dengan pidana yang berat, setidaknya dapat menjerakan pelaku dan mencegah tindak pidana lain yang akan menjadi pemicu tindak pidana pencucian uang. Ketidakmampuan dan inefisiensi sistem pemidanaan tindak pidana pencucian uang yang ada menunjukkan bahwa secara implisit memang pemidanaan terhadap tindak pidana pencucian uang itu sudah tepat ditujukan untuk menciptakan pidana yang proporsional dengan tingkat keparahan dampak yang ditimbulkan dari tindak pidana tersebut. Namun, terdapat beberapa hal terkait pemidanaan tindak pidana pencucian uang dalam UU No. 8 Tahun 2010 yang belum sepenuhnya mencerminkan cost and benefit principal $^{24}$.

\section{Maksimalisasi Pidana}

Adanya maksud pemaksimalan ancaman pidana terhadap pelaku tindak pidana pencucian uang sekilas telah memperhitungkan prinsip biaya dan manfaat (cost and benefit principle). Dalam konteks ini adalah dengan mempertimbangkan kerugian yang akan ditimbulkan dari aktivitas pencucian uang yang disepadankan dengan meningkatkan jumlah pidana yang akan dijatuhkan terhadap pelaku atau kesempatan pelaku untuk dapat ditangkap dan diadili. Namun, masih terdapat beberapa hal terkait rumusan pidana dan pemidanaan tindak pidana pencucian uang dalam UU No. 8 Tahun 2010, khususnya pada Pasal $3^{25}$, Pasal $4^{26}$, dan Pasal 527, yang tidak diikuti dengan cara

${ }^{24}$ Cost and benefit principal yaitu satu prinsip dalam economic analysis of law yang merupakan "suatu rangkaian teknikal yang digunakan dalam membuat keputusan terbaik dengan memperhitungkan segala bentuk estimasi kerugian dan keuntungan yang mungkin timbul dari usulan keputusan yang akan diajukan”. Dalam Fajar Sugiato, Economic Analysis to Law: Seri Analisis Ke-ekonomian tentang Hukum, Op. Cit., hlm. 103-104.

25 Setiap orang yang menempatkan, mentransfer, mengalibkan, membelanjakan, membayarkan, menghibabkan, menitipkan, membawa ke luar negeri, mengubah bentuk, menukarkan dengan mata uang atau surat berharga atau perbuatan lain atas harta kekayaan yang diketabuinya atau patut diduganya merupakan hasil tindak, pidana dengan tujuan menyembunyikan atau menyamarkan asal usul harta kekayaan dipidana karena tindak pidana Pencucian Uang dengan pidana penjara paling lama 20 tahun dan denda paling banyak Rp. 10.000.000.000,00. Indonesia, Undang-Undang tentang Pencegahan dan Pemberantasan Tindak Pidana Pencucian Uang, UU No. 8 Tahun 2010, LN. No. 122 Tahun 2010, TLN. No. 5164, Bab II, Pasal 3.

26 Setiap orang yang menyembunyikan atau menyamarkan asal usul, sumber, lokasi, peruntukan, pengalihan bak-hak, atau kepemilikan yang sebenarnya atas harta kekayaan yang diketabuinya atau patut diduganya merupakan hasil tindak pidana sebagaimana dimaksud dalam Pasal 2 ayat (1) dipidana karena tindak pidana Pencucian Uang dengan pidana penjara paling lama 20 tabun dan denda paling banyak Rp. 5.000.000.000,00. Indonesia, Undang-Undang tentang Pencegahan dan Pemberantasan Tindak Pidana Pencucian Uang, UU No. 8 Tahun 2010, LN. No. 122 Tahun 2010, TLN. No. 5164, Bab II, Pasal 4.

27 Setiap orang yang menerima atau menguasai penempatan, pentransferan, pembayaran, hibah, sumbangan, penitipan, penukaran, atau menggunakan harta kekayaan yang diketabuinya atau patut diduganya merupakan hasil tindak pidana sebagaimana dimaksud dalam Pasal 2 ayat (1) dipidana dengan pidana penjara paling lama 5 (lima) tahun dan denda paling banyak R. 1.000.000.000,00. Indonesia, Undang-Undang tentang Pencegahan dan Pemberantasan Tindak Pidana Pencucian Uang, UU No. 8 Tahun 2010, LN. No. 122 Tahun 2010, TLN. No. 5164, Bab II, Pasal 5, ayat (1). 
pengenaan yang efisien dan konsisten, sehingga tidak optimal dalam mencapai tujuan awal dari adanya pemaksimalan ancaman pidana itu sendiri.

\section{a. Pidana penjara}

Sekalipun pidana penjara diusahakan untuk tumbuh sebagai instrumen reformasi dengan pendekatan yang lebih manusiawi, namun memang merupakan suatu kenyataan bahwa keburukan atau kerugian (dalam kalkulasi untung-rugi) yang melekat pada pidana penjara akan sulit dihindari. Dalam pertimbangan cost and benefit principle, pidana penjara bukan saja tidak efektif tetapi juga tidak efisien dalam mencapai tujuan pemidanaan tindak pidana pencucian.

Ketidakefisienan ini adalah karena penggunaan pidana penjara hanya akan menciptakan biaya sosial yang sangat tinggi (high social cost of imperisoment) yang harus ditanggung oleh negara, yaitu salah satunya berupa biaya untuk pembinaan para narapidana dan biaya untuk membangun infrastruktur lembaga pemasyarakatan serta pemeliharaannya, terlebih jika pidana penjara tersebut dijalani dalam waktu yang lama (dalam konteks ini menjatuhkan pidana maksimum). Hal ini justru akan semakin mempertinggi jumlah kerugian (cost) yang ditanggung negara dalam hal penanggulangan tindak pidana pencucian uang. Bahkan, pengenaan pidana penjara dalam waktu yang lama terhadap pelaku sebenarnya tidak sepadan dengan jumlah kerugian negara dan jumlah harta kekayaan yang dapat dipulihkan dari tindak pidana pencucian uang yang telah dilakukan pelaku.

Tidak dapat dipungkiri bahwa bagaimanapun usaha-usaha pembaharuan dan perbaikan baik yang bersifat praktis maupun teoritis untuk mengurangi daya laku dari pidana penjara ini, tetap saja pidana penjara itu masih diperlukan dan akan ada. Setidaknya melalui penjatuhan pidana penjara ini dapat memenuhi tujuan pemidanaan terhadap tindak pidana yang dimaksud. Oleh karena itulah, penggunaan cost and benefit principal dalam konteks ini adalah bukan dimaksudkan agar pidana penjara harus dihilangkan dalam pemidanaan tindak pidana pencucian uang sebagaimana diatur dalam UU No. 8 Tahun 2010. Sebab, apabila mengacu pada pendapat Steven Shavell dan Mitchell Polinsky yang mana juga merupakan ahli dalam economic analysis of law, justru pidana yang sifatnya non-moneter yang lebih efisien untuk diterapkan terhadap white-collar crime. ${ }^{28}$ Begitu pun T.J Gunawan berpendapat bahwa

28 Steven Shavell dan Mitchell Polinsky menyebutkan, bahwa "...it is also possible that the optimal imprisonment terms is greater for the higher wealth group. This might occur because imprisonment is a more 'cost effective' detterent when applied to the wealthy group... Because of the greater cost-effectiveness of imprisoment when applied to the higher wealth group, it may be desirable to achieve a higher level of detterence with respect to that group". Dalam Andreas Nathaniel Marbun dan Revi Laracaka, Op. Cit., hlm. 136. 
"pidana penjara masih dapat diterapkan terhadap tindak pidana berbasis ekonomi"29 sekalipun. Inilah mengapa kemudian Barda Nawawi Arief menyebutkan bahwa kritik terhadap pidana penjara perlu didasarkan pada bagaimana mempertahankan pidana penjara namun penggunaannya dibatasi.

Sejalan dengan hal tersebut, salah satu konsep pemidanaan menurut economic analysis of ciriminal law yang didasarkan pada cost and benefit principle, bahwa pidana penjara akan tetap dapat dijatuhkan, namun diperlukan pencabutan seluruh batasan maksimum pidana yang dapat dijatuhkan kepada pelaku tindak pidana tersebut. Sebagaimana dalam rumusan Pasal 3 dan Pasal 4 yang menentukan pidana penjara paling lama 20 tahun dan Pasal 5 yang menentukan pidana penjara paling lama 5 tahun. Sistem perumusan ancaman pidana yang menggunakan sistem maksimum khusus (indefinite) seperti itu, dalam konteks hukum pidana Indonesia yang dimulai dari minimum umum 1 hari sampai dengan maksimum khusus sebagaimana diatur dalam tiap-tiap pasal (Pasal 3, Pasal 4, Pasal 5) akan menimbulkan persoalan manakala terjadi kesenjangaan antara maksimum pidana yang diancamkan dengan pidana yang dijatuhkan, terlebih jika pidana yang dijatuhkan itu tidak proporsional dengan keseriusan dampak yang ditimbulkan atas tindak pidana. Kesenjangan ini akan menimbulkan kesan ketidakadilan manakala pidana yang dijatuhkan bukan pidana maksimum atau lebih ringan dan hal ini semakin menambah keuntungan (benefit) yang diperoleh pelaku.

Perspektif economic analysis of criminal law menganggap ketentuan batasan maksimum pidana penjara tersebut bertentangan dengan cost and benefit principal, bahkan dalam konteks tujuan pemidanaan tindak pidana pencucian uang pun hal ini bertentangan dengan konsep maksimalisasi pemidanaan itu sendiri. Bentham menekankan bahwa "nilai penghukuman harus tidak boleh kurang dalam segala kasus terhadap apa yang cukup untuk menimbang berat keuntungan pelanggaran"30. Artinya, bahwa pemidanaan yang diberikan semestinya tidak boleh memberikan celah untuk peluang keuntungan yang lebih besar yang didapat pelaku atas tindak pidana yang dilakukan. Karena itu, beban pemidanaan-penjara yang dijatuhkan dan dijalani haruslah sepadan dengan kerugian ekonomi yang ditimbulkan dan tidak dikembalikan kepada korban. Serta tidak boleh dikurangi dalam bentuk apa pun. ${ }^{31}$ Bagaimanapun, konsep maksimalisasi pidana penjara yang efisien terhadap tindak pidana

${ }^{29}$ Termasuk dalam konteks ini tindak pidana pencucian uang yang merupakan tindak pidana yang dilatarbelakangi oleh motif ekonomi.

30 T.J. Gunawan, Konsep Pemidaaan Berbasis Nilai Kerugian Ekonomi, Cetakan Pertama, Genta Press, Yogyakarta, 2015, hlm. 168.

31 Ibid., 
pencucian uang adalah yang diharapkan mampu memberikan pemahaman kepada pelaku ataupun masyarakat bahwa perbuatan tindak pidana itu tidak akan pernah lebih menguntungkan (memberikan benefit secara penuh).

\section{b. Pidana denda}

Sebagaimana halnya pidana penjara, rumusan pidana denda dalam pemidanaan tindak pidana pencucian uang sebagaimana diatur dalam UU No. 8 Tahun 2010 juga dirumuskan secara indefinit (indefinite sentence system) atau dalam pola maksimal khusus yang mana batas minimum pidananya akan didasarkan pada ketentuan umum dalam KUHP. Meskipun pidana denda dalam UU No. 8 Tahun 2010 ini telah ditentukan dalam jumlah yang besar dan dalam pola maksimal khusus, yaitu sebagaimana tertuang dalam rumusan Pasal 3 paling banyak Rp. 10.000.000.000,00, dalam Pasal 4 paling banyak Rp. 5.000.000.000,00, dan dalam Pasal 5 paling banyak Rp. 1.000.000.000,00, namun pada kenyataannya justru menjadi tidak efektif dan efisien. Artinya, "perkembangan untuk memperluas penggunaan pidana denda dengan meningkatkan jumlah ancaman pidana denda saja, ternyata belum mencukupi untuk meningkatkan efektivitas pidana denda"32 dalam menanggulangi masalah tindak pidana pencucian uang. Hal ini dikarenakan cara pengenaan pidana denda terhadap tindak pidana pencucian uang tersebut tidak efisien dan cenderung tidak konsistem dalam pengenaannya.

Apabila memandang dalam pertimbangan cost and benefit princple, pidana denda dalam pemidanaan tindak pidana pencucian uang sebagaimana diatur dalam UU No. 8 Tahun 2010 (khususnya pada Pasal 3, Pasl 4, dan Pasal 5) ini justru terlihat belum efektif dan efisien dalam memaksimalkan pemidanaan terhadap pelaku tindak pidana pencucian uang yang berorientasi pada motif ekonomi tersebut. Ketidakefektifan pidana denda atas tindak pidana ini terbukti dengan besarnya kerugian negara yang tidak sebanding dengan besarnya pidana denda yang dijatuhkan kepada pelaku tindak pidana pencucian uang. Selama Januari 2003 sampai dengan November 2018 saja, dalam data statistik yang disusun oleh PPATK 33 menyebutkan jumlah total denda dari 156 putusan pengadilan hanya mencapai Rp. 20.900.000.000,00. Jumlah total denda terhadap tindak pidana pencucian uang tersebut bahkan tidak sebanding dengan jumlah kerugian yang ditaksir berdasarkan data putusan pengadilan tindak pidana pencucian uang, yang mana dalam 2018 saja sudah dapat mencapai Rp. 8.500.000.000.000,00.

32 Yesmil Anwar dan Adang, Pembaruan Hukum Pidana: Reformasi Hukum, Cetakan Pertama, Grasindo, Jakarta, 2008, hlm. 163.

33 Buletin Statistik “Anti Pencucian Uang dan Pencegahan Pendanaan Terorisme”, Edisi November 2018, Volume 105/THN IX/2018. 
Tabel 1. Jumlah Kerugian yang Ditaksir

Berdasarkan Data Putusan Pengadilan TPPU Tahun $2018^{34}$

\begin{tabular}{|c|c|c|}
\hline Jenis Tindak Pidana Asal & $\begin{array}{l}\text { Jumlah } \\
\text { Putusan }\end{array}$ & $\begin{array}{l}\text { Total Kerugian } \\
\text { (dalam Rupiah) }\end{array}$ \\
\hline Murni TPPU & 1 & 1.000 .000 .000 \\
\hline Korupsi & 9 & 133.311.085.956 \\
\hline Narkotika & 22 & 6.684.668.606.344 \\
\hline Penggelapan & 3 & 945.364 .024 .010 \\
\hline Di bidang perbankan & 3 & 430.495 .607 .693 \\
\hline Di bidang perpajakan & 1 & 161.176.032.108 \\
\hline Penipuan & 6 & 86.083.102.579 \\
\hline Tindak pidana lain ( $>4$ tahun pidana penjara) & 7 & 48.689 .400 .600 \\
\hline Di bidang perasuransian & 1 & 35.500 .000 .000 \\
\hline Total & 54 & 8.526 .296 .859 .290 \\
\hline
\end{tabular}

Perspektif cost and benefit princple memposisikan pidana denda sebagai utilitas negatif bagi pelaku tindak pidana. Dalam konteks pemidanaan tindak pidana pencucian uang, perlu dipahami bahwa pidana denda dijatuhkan atas perhitungan denda adalah dampak dari pendapatan hasil tindak pidana yang semestinya seimbang dengan besaran benefit yang diharapkan dari pendapatan hasil tindak pidana tersebut. Namun, pidana denda ini justru tidak memberikan cost terhadap pelaku, sebab UU No. 8 Tahun 2010 hanya menentukan besaran denda tanpa diikuti ketentuan mengenai tindakan-tindakan lain yang dapat menjamin agar terpidana dapat dipaksa untuk membayarkan denda tersebut. ${ }^{35}$ Terpenting tidak ada batas waktu pembayaran denda dan tindakan-tindakan paksaan lainnya yang dapat menjamin terlaksananya pidana denda yang dijatuhkan tersebut. Artinya, pidana denda tidaklah bersifat wajib untuk dilaksanakan oleh pelaku tindak pidana pencucian uang. Terlebih pelaksanaan pidana denda tersebut dapat saja digantikan oleh bukan pelaku, yang mana menyebabkan rasa dipidananya pelaku justru menjadi hilang.

Antara pidana penjara dan pidana denda itu seolah-olah tidak berbeda, sebab pidana denda yang dimaksudkan sebagai pidana yang berorientasi pada motif ekonomi/moneter, justru dalam pelaksanaannya seperti pidana badan atau pidana hilang kemerdekaan. Hal ini karena adanya alternatif pidana yang dimungkinkan dalam hal terpidana tidak mau atau tidak mampu membayar

34 Dalam Laporan Hasil Riset Tipologi tahun 2009 oleh Pusat Pelaporan dan Analisis Transaksi Keuangan (PPATK) Indonesia, “Tipologi Pencucian Uang Berdasarkan Putusan Pengadilan Tahun 2018”.

35 Dikarenakan pola pelaksanaan pemidanaan dalam UU No. 8 Tahun 2010 masih terikat oleh ketentuan dalam KUHP, maka sebagaimana ketentuan dalam Pasal 31 KUHP dapat disimpulkan bahwa yang dihukum pidana denda pada dasarnya bebas untuk memilih antara membayar denda yang dijatuhkan atau menjalani hukuman kurungan pengganti. 
denda, yaitu mengenakan pidana kurungan (kurungan subsider atau pengganti), tetapi bukan pidana kurungan principal. Hal ini pun yang justru menjadikan tidak efektifnya pidana denda dalam mewujudkan maksimalisasi pidana dan tujuan pemidanaan tindak pidana pencucian uang itu sendiri.

Menurut pandangan economic analysis of criminal law, pelaku tindak pidana pencucian uang merupakan rational actor, yaitu pelaku akan berusaha memaksimalkan utilitas mereka dalam konteks kriminal. Pelaku akan membandingkan cost yang diharapkan dari kegiatan kriminal dengan benefit yang diharapkannya. Dengan mempertimbangkan cost dan benefit tersebut, maka pelaku tindak pidana tersebut akan memperhitungkan untuk lebih baik menjalankan pidana kurungan dibandingkan untuk membayar denda yang sangat besar. Dengan demikian, tidak akan ada kerugian moneter yang lebih besar terhadap pelaku dan akan memungkinkan memperbesar benefit (dalam nilai moneter) yang diperoleh pelaku. Namun, justru jumlah pidana denda yang seharusnya dapat masuk sebagai benefit negara (bukan pajak) akan menjadi cost untuk membiayai pelaku dalam kurungan.

\section{Pemulihan Aset (Asset Recovery)}

Pemulihan aset dalam konteks pencegahan dan pemberantasan tindak pidana pencucian uang ini adalah bertujuan untuk memutuskan hubungan pelaku dengan aset yang dimilikinya dari hasil tindak pidana dengan cara menelusuri dan merampas aset tersebut. Fokus dari pemulihan aset adalah memprioritaskan penelusuran atas aset yang dimungkinkan dapat menjadi motivasi untuk berkembangnya tindak pidana lainnya, serta perampasan atas aset hasil tindak pidana atau kejahatan lain sehingga dapat dikembalikan kepada yang berhak atau negara. Hal ini diharapkan agar pelaku dapat secara rasional mengambil keputusan untuk tidak melakukan tindak pidana pencucian uang.

Dalam perspektif cost and benefit principle, ketentuan pemulihan aset dalam pemidanaan tindak pidana pencucian uang memposisikan objek penanggulangan kejahatan bukan lagi untuk menghilangkan kejahatan itu sama sekali. Seperti halnya pemidanaan tindak pidana pencucian uang yang didasari oleh asumsi "follow the money", yaitu suatu pendekatan yang mana mendahulukan mencari uang atau harta kekayaan hasil tindak pidana dibandingkan dengan mencari pelaku tindak pidana ${ }^{36}$, sebagaimana pendekatan penanggulangan kejahatan umumnya. Uang atau harta kekayaan ibarat darah bagi bisnis dan industri yang

${ }^{36} \mathrm{Ni}$ Komang Sutrisni dan A.A. Kaetut Sukranata, "Pendekatan Follow the Money dalam Penelusuran Tindak Pidana Pencucian Uang serta Tindak Pidana Lain”, hlm. 3. dalam https://ojs.unud.ac.id/index.php/ kerthasemaya/article/download/4684/3555\#: :text=harta \%20kekayaan \%20lain.-,Pendekatan $\% 20$ follow $\% 20$ the $\% 20$ money $\% 20$ mendahulukan $\% 20$ mencari $\% 20$ uang $\% 20$ atau $\% 20$ harta $\% 20$ kekayaan,dan $\% 20$ tindak $\% 20$ pidan a\%20yang\%20dilakukan, Akses 9 Juni 2020. 
sah, demikian juga bagi organisasi-organisasi kejahatan, baik nasional maupun internasional. 37

John C Keeney juga menyetujui hal tersebut, bahwa "allowing illegally earned money to pass through society sustains criminal operations, for money is the lifeblood of any criminal organization" 38 . Karena itu, ide yang ingin ditekankan dalam konteks ini, adalah bahwa "money laundering is the blood of the crime". Pencucian uang merupakan "darah" dari kejahatan asal itu sendiri. Dengan demikian, menghentikan "peredaran darah" telah mengancam kelangsungan hidup dari suatu organisasi kriminal. Namun demikian, konsep tersebut hanya akan dapat diterapkan apabila terdapat dugaan atas sangkaan tindak pidana pencucian uang yang dilakukan oleh pelaku (tindak pidana asal, seperti halnya tindak pidana korupsi), yang mana dapat digunakan dalam menelusuri sejauh mana aset tersebut mengalir.

Dalam ketentuan UU No. 8 Tahun 2010 memang ditetapkan mengenai perampasan aset. Namun cara ini hanya merupakan pidana tambahan yang bersifat fakultatif dan hanya dalam hal-hal tertentu saja bersifat imperatif. Pasal 67 UU No 8 Tahun 2010 menegaskan bahwa dimungkinkan dilakukan upaya perampasan aset tanpa pemidaaan, atau dikenal dengan sebutan non conviction based (NCB). Namun aset atau barang-barang yang dapat dirampas hanyalah aset atau barang-barang yang diperoleh dari tindak pidana atau yang sengaja dipergunakan untuk melakukan tindak pidana. Hal ini tentu saja menunjukkan bahwa upaya pemulihan aset dengan cara perampasan atas aset hasil tindak pidana sebernya belum efisien, sehingga belum optimal menanggulangi masalah tindak pidana pencucian uang. Dari pemantauan PPATK sendiri menyebutkan bahwa upaya perampasan aset belum optimal, khususnya terhadap hasil tindak pidana yang tidak dapat atau yang sulit dibuktikan tindak pidananya. ${ }^{39}$

\section{Penutup}

\section{Kesimpulan}

Setelah menganalisis pemidanaan terhadap tindak pidana pencucian uang yang selanjutnya termuat dalam UU No. 8 Tahun 2010 tentang Pencegahan dan Pemberantasan Tindak Pidana Pencucian Uang ternyata masih belum

37 Sutan Remy Sjahdeini, Seluk Beluk Tindak Pidana Pencucian Uang dan Pembiayaan Terorisme, Cetakan Pertama, Pustaka Utama Grafiti, Jakarta, 2004, hlm. 27.

38 Ibid., hlm. 28.

39 Mas Alamii Huda, "PPATK Dorong RUU Perampasan Aset segera ditetapkan", diterbitkan pada 29 April 2021, dalam https://www.republika.co.id/berita/qsbbge487/ppatk-dorong-ruu-perampasan-aset-segeraditetapkan, Akses 9 Juni 2021. 
sepenuhnya mencerminkan prinsip cost and benefit principle, sehungga cenderung menciptakan pemidanaan yang tidak efisien.

\section{Saran}

Dalam rangka meluruskan paradigma penanggulangan tindak pidana pencucian uang yakni dari follow the suspect menjadi follow the money, maka penjatuhan pidana (pemidanaan) terhadap tindak pidana pencucian uang akan lebih tepat jika menggunakan pendekatan economic analysis of criminal law. Hal ini dikarenakan bahwa pemidanaan terhadap tindak pidana pencucian uang masih bersifat represif dan hal ini belum optimal menanggulangi peningkatan kuantitas dan kualitas perkara tindak pidana pencucian uang dari tahun ke tahun, bahkan belum mampu mengoptimalkan pemulihan atas aset dari hasil tindak pidana atau yang dimungkinan dapat mendanai tindak pidana lainnya. Melalui pendekatan economic analysis of criminal law, diharapkan dapat mengoptimalkan tercapainya pemidanaan yang proporsional untuk tindak pidana pencucian uang, sehingga lebih efisien dalam rangka mencegah dan memberantasan tindak pidana pencucian uang.

\section{Daftar Pustaka}

\section{Buku}

Anwar, Yesmil dan Adang, Pembaruan Hukum Pidana: Reformasi Hukum, Cetakan Pertama, Grasindo, Jakarta, 2008.

Atmasasmita, Romli dan Kodrat Prabowo, Analisis Ekonomi Mikro tentang Hukum Pidana Indonesia, Cetakan Kedua, Kencana, Jakarta, 2016.

Bagaric, Mirko, Punishment and Sentencing: A Rational Approach, First Edition, Cavendish Publishing Limited, London, 2001.

Garnasih, Yenti, Penegakan Hukum Anti Pencucian Uang dan Permasalahannya di Indonesia, Cetakan Keempat, Rajawali Pers, Depok, 2017.

Gunawan, T.J, Konsep Pemidanaan Berbasis Nilai Kerugian Ekonomi: Menuju Sistem Hukum Pidana yang Berkeadilan, Berkepastian, Memberi Daya Deteren dan Mengikuti Perkembangan Ekonomi, Cetakan Pertama, Genta Press, Yogyakarta, 2015.

Halim, Pathorang, Penegakan Hukum terhadap Kejahatan Pencucian Uang di Era Globalisasi. Cetakan Pertama, Total Media, Yogyakarta, 2013.

Haswandi et.al, Sistem Pemidanaan Terhadap Pelaku Tindak Pidana Pencucian Uang. Cetakan Pertama, Puslitbang Hukum dan Peradilan Mahkamah Agung RI, Jakarta, 2017.

Ibrahim, Johnny, Pendekatan Ekonomi terhadap Hukum: Teori dan Implikasi Penerapannya dalam Peengakan Hukum, Cetakan Pertama, Putra Media Nusantara, Surabaya, 2009. 
K, Roberts, Pengembalian Aset Hasil Kejahatan dalam Perspektif Rezim Anti Pencucian Uang, Cetakan Pertama, Rajawali Pers, Depok, 2017.

Muladi dan Barda Nawawi Arief. Teori-teori dan Kebijakan Pidana. Cetakan Keempat, Alumni, Bandung, 2010.

Redaksi Bhafana Publishing, KUHP (Kitab Undang-Undang Hukum Pidana) dan KUHAP (Kitab Undang-Undang Hukum Acara Pidana), Cetakan Pertama, Bhafana Publishing, Jakarta, 2019).

Sjahdeini, Sutan Remy, Seluk Beluk Tindak Pidana Pencucian Uang dan Pembiayaan Terorisme, Cetakan Pertama, Pustaka Utama Grafiti, Jakarta, 2004.

Sugiato, Fajar, Economic Analysis to Law: Seri Analisis Ke-ekonomian tentang Hukum, Cetakan Kedua, Kencana, Jakarta, 2015.

Sulhin, Iqrak, Diskontinuitas Penologi Punitif: Sebuah Analisis Genealogis terhadap Pemenjaraan, Cetakan Pertama, Kencana, Jakarta2016.

Syamsu, Muhammad Ainul, Penjatuhan Pidana dan Dua Prinsip Dasar Hukum Pidana. Cetakan Pertama, Kencana, Jakarta, 2016.

Jurnal

Andreas Nathaniel Marbun,dan Revi Laracaka, "Analisa Ekonomi terhadap Hukum dalam Pemidanaan Partai Politik melalui Pertanggungjawaban Korporasi dalam Perkara Tipikor", Jurnal Antikorupsi, Edisi No.1 Vol.5, (2019).

Joel Goh, "Proportionality-An Unattainable Ideal in the Criminal Justice System", Manchester Student Law Review, Edisi No.41 Vol.2, (2013)

Lidya Suryani Widayati. "Pidana Mati dalam RUU KUHP: Perlukah Diatur sebagai Pidana yang Bersifat Khusus?", Jurnal Negara Hukum, Edisi No.2 Vol.7, (2016).

Michael J. Trebilcock, "Law and Economics", the Dalhousie Law Journal, Edisi No.2 Vol. 16, (1993).

Padjadjaran, “Jeremy Bentham”, Jurnal Ilmu Hukum, Edisi No. 2 Vol. 2, (2015).

Richard A.Posner, "an Economic Theory of the Criminal Law", Columbia Law Review, Edisi No.6 Vol 85, (1985).

\section{Buletin dan Hasil Penelitian}

Buletin Statisktik "Anti Pencucian Uang dan Pencegahan Pendanaan Terorisme", Edisi November 2018, Vol. 105/THN IX/2018.

Buletin Statistik "Anti Pencucian Uang dan Pencegahan Pendanaan Terorisme", Edisi Desember 2020, Volume 130/THN X/2020.

Laporan Hasil Riset Tipologi tahun 2009 oleh Pusat Pelaporan dan Analisis Transaksi Keuangan (PPATK) Indonesia, “Tipologi Pencucian Uang Berdasarkan Putusan Pengadilan Tahun 2018".

\section{Media Elektronik}

Huda, Mas Alamii. "PPATK Dorong RUU Perampasan Aset segera ditetapkan", diterbitkan pada 29 April 2021, dalam https://www.republika.co.id/ 
berita / qsbbge487/ppatk-dorong-ruu-perampasan-aset-segeraditetapkan

Sutrisni, Ni Komang dan A.A. Kaetut Sukranata, "Pendekatan Follow the Money dalam Penelusuran Tindak Pidana Pencucian Uang serta Tindak Pidana Lain", Dalam https://ojs.unud.ac.id/index.php/kerthasemaya/ article/download/4684/3555\#: :text=harta\%20kekayaan\%20lain.,Pendekatan\%20follow\%20the\%20money\%20mendahulukan\%20mencari \%20uang\%20atau\%20harta\%20kekayaan,dan\%20tindak\%20pidana\%20y ang\%20dilakukan

\section{Peraturan Perundang-undangan}

Kitab Undang-Undang Hukum Pidana

Undang-Undang Nomor 8 Tahun 2010 tentang Pencegahan dan Pemberantasan Tindak Pidana Pencucian Uang.

Peraturan Kepala Pusat Pelaporan dan Analisis Transaksi Keuangan Nomor: PER-02/1.02/PPATK/02/15 tentang Kategori Pengguna Jasa yang Berpotensi Melakukan Tindak Pidana Pencucian Uang. 